\title{
Behçet disease: our experience
}

\author{
Doença de Behçet ocular: a nossa realidade
}

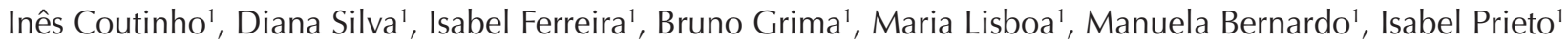

\begin{abstract}
Objective: Behçet's disease is a systemic inflammatory vasculitis of unknown etiology. It can virtually reach all systems, being common ocular manifestations. The aim of this study was to analyze patients with ocular Behcet's disease regarding demographic parameters, clinical manifestations, therapeutic approach and main complications. Methods: Descriptive and retrospective study, including 11 patients diagnosed with ocular Behcet's disease, according to the ISG criteria, observed in the Ocular Inflammation appointment of the Hospital Prof. Doutor Fernando da Fonseca in the last 3 years. Results: We identified 11 patients, 5 males and 6 females, all caucasian. The mean age at diagnosis was $33.45 \pm 6.49$ years. Ocular manifestation was the first sign of the disease in 2 patients. In $72.7 \%$ of the cases, ocular manifestations were bilateral. There were four cases of panuveitis, 3 of posterior uveitis, 2 of anterior uveitis, 1 of keratitis and 1 case of episcleritis. Glaucoma and cataract were the most frequent ocular complications. Systemic treatment included oral corticosteroid therapy in combination with adjuvant immunosuppressive therapy, and the most commonly used was azathioprine and cyclosporine. In 3 patients there was a need for biological treatment with infliximab to control the disease. Conclusion: The most frequent ocular manifestation was panuveitis. This disease can promote eye complications with an irreversible decrease in visual acuity. Orientation of these patients requires a global and interdisciplinary approach.
\end{abstract}

Keywords: Behçet syndrome/complications; Behçet syndrome/diagnosis; Eye manifestations

\section{RESUMO}

Objetivo: A doença de Behçet é uma vasculite inflamatória sistémica, de etiologia desconhecida. Pode atingir virtualmente todos os sistemas, sendo as manifestações oculares comuns. O objectivo deste trabalho foi analisar doentes com doença de Behçet ocular quanto aos parâmetros demográficos, manifestações clinicas, terapêutica e principais complicações. Métodos: Estudo descritivo e retrospetivo, que incluiu 11 doentes com o diagnóstico de doença de Behçet ocular, segundo os critérios do ISG, observados na consulta de Inflamação Ocular do Hospital Prof. Doutor Fernando da Fonseca nos últimos 3 anos. Resultados: Identificaram-se 11 doentes, 5 homens e 6 mulheres, todos caucasianos. A idade média ao diagnóstico foi de 33,45 6 ,49 anos. A manifestação ocular foi o primeiro sinal da doença em 2 doentes. Em 72,7\% dos casos as manifestações oculares foram bilaterais. Identificaram-se 4 casos de panuveíte, 3 de uveíte posterior, 2 de uveíte anterior, 1 de queratite e 1 caso de episclerite. $O$ glaucoma e a catarata foram a complicação ocular mais frequente. $\mathrm{O}$ tratamento sistémico incluiu a corticoterapia oral em associação com terapêutica adjuvante imunossupressora, sendo os mais utilizados a azatioprina e a ciclosporina. Em 3 doentes houve necessidade de terapêutica biológica com infliximab para controlo da doença. Conclusão: A manifestação ocular mais frequente foi a panuveíte. Esta doença pode condicionar complicações oculares com diminuição irreversível da acuidade visual. A orientação destes doentes exige uma abordagem global e interdisciplinar.

Descritores: Sindrome de Behçet/complicações; Sindrome de Behçet/diagnóstico; Manifestações oculares

\footnotetext{
${ }^{1}$ Hospital Prof. Doutor Fernando Fonseca, EPE, Portugal.

The authors declare no conflict of interests.

Received for publication 15/12/2016 - Accepted for publication 11/05/2017.
} 


\section{INTRODUCTION}

B ehcet's disease is an inflammatory, systemic vasculitis of unknown etiology. It is characterized by recurrent episodes of oral and genital ulcers, ocular and cutaneous lesions, as well as vascular, articular, gastrointestinal or neurological lesions. ${ }^{(1,2)}$

A prevalence of $2.4 / 00,000$ cases is estimated in Portugal. ${ }^{(3)}$

Behçet's disease usually occurs between the 2nd and 4th decade of life, ${ }^{(3)}$ although it may affect any age, with no difference in the socioeconomic distribution. ${ }^{(3,4)}$ It is discretely more prevalent in males in which, due to an increased risk of ocular, cardiovascular or neurological involvement and an earlier age of manifestation, is associated with a worse prognosis. ${ }^{(1)}$

Although its etiology is unknown, it is believed to be due to an autoimmune process triggered by an infection or environmental agent in genetically predisposed individuals. ${ }^{(2)}$ The HLA-B51 allele located on chromosome $6 p$ has been associated to the disease.

For the diagnosis of Behçet's disease, there are no clinical or laboratory pathognomonic findings, but several clinical criteria for diagnostic assistance, one of which published by the International Study Group (ISG) in 1990 (Table 1), ${ }^{(1)}$ having no consensus on which will be the best one. ${ }^{(5)}$

\section{Table 1}

\section{Criteria for the diagnosis of Behçet's disease - ISG}

\section{Recurrent Oral Ulcers (at least 3 times over 1 year) \\ +2 of the following characteristics}

Recurrent Genital Ulcers

Ocular lesion (anterior uveitis, posterior uveitis, vitritis or retinal vasculitis)

Cutaneous lesions (Erythema nodosum,pseudofolliculitis or papulopostular lesions; acneiform nodules in a post-adolescent patient and not subject to corticosteroid therapy)

Positive Patergia Test (with pustule formation after 24-48h at the site of the prick with sterile needle)

The diagnosis of Behçet's disease can be difficult and sometimes delayed, since the various manifestations of the disease ${ }^{(4)}$ may appear spaced for years.

The ocular involvement occurs in $30-70 \%$ of patients with Behçet's, usually in the first 2-3 years after the initial symptoms of the disease, although it may be the initial sign of the disease in $10-15 \% .^{(5)}$

The ocular involvement may occur in the form of uveitis and, in more rare cases, episcleritis and keratitis. The anterior uveitis is typically non-granulomatous, with mobile hypopyon occurring in $1 / 3$ of patients. The involvement of the posterior segment, more common in males, is characterized by recurrent episodes of occlusive retinal vasculitis, which affects both veins and arteries, vitritis and retinitis lesions.

Ocular attainment is a significant cause of morbidity and may cause blindness in $25 \%$ of patients after 10 years, despite treatment. ${ }^{(5)}$

The treatment aims at the relief of symptoms and a rapid resolution of inflammation, preventing or limiting tissue damage, frequency and severity of the episodes to avoid complications. ${ }^{(1)}$

The therapy of choice is according to the organ involved and the extent and severity of the disease, and the best treatment can only be planned in an interdisciplinary model.

\section{Methods}

A descriptive and retrospective study including 11 patients diagnosed with ocular Behçet's disease observed during appointment of Ocular Inflammation at Hospital Prof. Doctor Fernando da Fonseca between January 2013 and 2016. All patients were followed in parallel during the appointment for autoimmune diseases at the same hospital.

\section{ResULTS}

\section{Demographic characteristics}

Of the 11 patients studied with ocular Behcet's disease, 5 men $(45.45 \%)$ and 6 women $(54.55 \%)$ were identified, all caucasian.

The average age during diagnosis was $33.45 \pm 6.49$ years.

\section{Diagnosis}

Oral aphthosis appeared as the first manifestation in 9 patients, followed by the ocular one in 2 patients. In the last 2 patients, the time elapsed between the onset of ocular manifestation and the diagnosis of Behçet's disease was 1.5 years.

The ocular manifestations appeared at about 34 years of age, about 2.5 years after the first manifestations of the disease.

The clinical manifestations are summarized in table 2 .

The HLA B51 allele was performed in $72.2 \%$ of the patients, with a positive result in only $18.18 \%$ of cases $(n=2)$.

\section{Table 2}

\section{Manifestations of Behçet's disease in the sample}

\begin{tabular}{lc}
\hline Manifestation of the disease & Número de doentes $\mathbf{n}(\%)$ \\
\hline Oral ulcers & $11(100)$ \\
Ocular lesion & $11(100)$ \\
Genital ulcers & $7(63.63)$ \\
Dermatological lesion & $7(63.63)$ \\
Neurological lesion & $3(27.27)$ \\
Thromboembolic events & $4(36.36)$ \\
Joint lesion & $7(63.63)$ \\
\hline
\end{tabular}

\section{Characterization of ocular involvement}

The ocular involvement was bilateral $72.72 \%(n=8)$ of the sample.

Uveitis was the most frequent ocular manifestation $(81.81 \%)$, reporting 1 case of filamentous keratitis and 1 case of episcleritis.

Of the patients with uveitis, $36.36 \%$ presented panuveitis, followed by posterior uveitis with $27.27 \%$ and anterior uveitis with $18.18 \%$ (figure 1 ).

All cases of uveitis were non-granulomatous. There was no case of hypopyon. The involvement of the posterior segment occurred with vitritis $(n=7)$, papilla edema $(n=2)$, perivasculitis $(\mathrm{n}=5)$, and branch venous occlusion $(\mathrm{n}=2)$.

Ocular complications and visual acuities

Ocular complications were documented in 4 patients. 


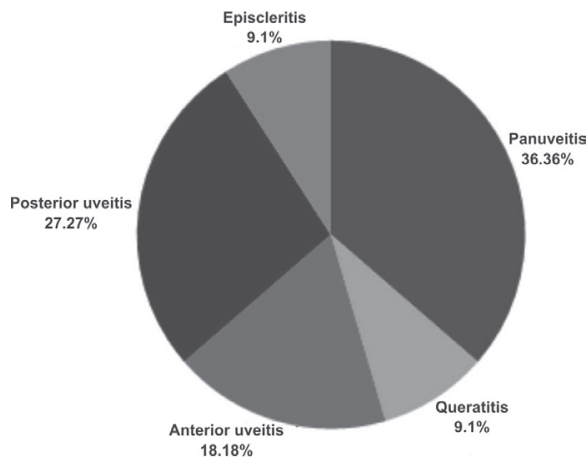

Figure 1. Distribution of the ocular manifestations

The most frequent ones were glaucoma and cataract $(27.27 \%, \mathrm{n}=3)$ (table 3$)$, followed by posterior synechiae (1 case), macular edema (1 case), and atrophy of the optic nerve (1 case).

The visual acuity (AV) ranged from light perception to $20 / 20$, with the average value of 20/25.

There were no differences between the two genders as regarding ocular complications.

\section{Therapy}

Patients were followed up simultaneously during the appointment for autoimmune diseases, as the comprehensive and detailed assessment of the patient is critical, as well as an experienced clinical team to handle immunosuppressive therapy and its possible adverse effects.

Topical therapy consisted of corticotherapy, mydriatic, and hypotensors whenever necessary. Systemic treatment included oral corticosteroid therapy in combination with other immunosuppressive adjuvants, with the most commonly used being azathioprine, cyclosporine and colchicine. In 3 patients there was need for biological therapy with infliximab for disease control.

Table 3

\section{Manifestations of Behçet's disease in the sample}

\begin{tabular}{lc}
\hline Ocular complications & Number of patients (n) \\
\hline Glaucoma & 3 \\
Cataract & 3 \\
Posterior synechiae & 1 \\
Macular edema & 1 \\
Atrophy of the optic nerve & 1 \\
\hline
\end{tabular}

\section{DISCUSSION}

When analyzing our results, we must bear in mind that the sample is not significant, requiring that the interpretation and extrapolation of the results be cautious. However, this study was useful for the authors to know the reality of their hospital.

The main ocular manifestation was bilateral panuveitis, which is in agreement with other similar studies. ${ }^{(2,6)}$

Although hypopyon is described in the literature as one of the classic findings of anterior uveitis in this disease and present in $20-30 \%$ of cases, in our study there was no record. This finding is consistent with the more recent studies ${ }^{(4)}$ in which there is a reduction in the prevalence of hypopion, and it may be due to the aggressive, early anti-inflammatory treatment with new drugs available.
In 2 patients, the first manifestation of the disease was branch venous occlusion, and the diagnosis of Behçet's disease was established after 1 and 2 years, respectively.

The importance of fluorescein angiography in the evaluation and monitoring of the disease activity is emphasized.

Theoretically, a higher prevalence of the disease would be expected in males. However, a recent series with greater meaning also showed gender equality. ${ }^{(3)}$

Ocular involvement in this disease, along with neurological disease, is an important cause of morbidity in Behçet's disease, which may compromise vision as observed in this study.

Whenever possible, the treatment of this pathology requires a multidisciplinary approach, using immunosuppressive drugs from several pharmacological groups, which is challenging. ${ }^{(1)}$ As a corticosteroid-sparing immunosuppressive drug, colchicine is primarily aimed at controlling mucocutaneous symptoms, and azathioprine and cyclosporin control the ocular symptoms. More recently, good results have been achieved with biological therapy with the anti-TNF- $\alpha$ monoclonal antibody, Infliximab. However, the best therapeutic regimen is not yet defined. ${ }^{(1)}$

The VA was over $20 / 25$ in 8 patients. In the remaining three, the VA of light perception and 20/200 was verified, and said reduced VA can be attributed to the optic nerve lesion with the development of glaucoma (in two cases) or by the occlusive process of the optic nerve itself.

\section{Conclusions}

Ocular involvement in Behçet's disease is common, hence it constitutes one of the major features to the diagnosis of this pathology.

The multiplicity of forms of presentation and the absence of pathognomonic signs make Behçet's disease a diagnosis of exclusion, being a challenging diagnosis, and the therapeutic orientation of these patients require an interdisciplinary work.

The treatment of this disease is difficult, but the new immunosuppressive drugs are an asset.

\section{REFERENCES}

1. Mendes D, Correia M, Barbedo M, Vaio T, Mota M, Gonçalves O, Valente J. Behçet's disease - a contemporary review. J Autoimmun. 2009;32(3-4):178-88.

2. Tugal-Tutkun I. Behçet's uveitis. Middle East Afr J Ophthalmol. 2009;16(4):219-24

3. Crespo J. Doença de Behçet: casuística nacional. Med Interna. 1997;4(4):225-32.

4. Deuter CM, Kötter I, Wallace GR, Murray PI, Stübiger N, Zierhut M. Behçet's disease: ocular effects and treatment. Prog Retin Eye Res. 2008;27(1):111-36.

5. Nussenblatt RB, Whitcup SM. Uveitis, fundamentals and clinical practice. 4th ed. Elsevier; 2014. Behçet's disease. Chapter 26.

6. Tugal-Tutkun I, Onal S, Altan-Yaycioglu R, Huseyin Altunbas H, Urgancioglu M. Uveitis in Behçet disease: An analysis of 880 patients. Am J Ophthalmol. 2004 Sep;138(3):373-80.

\section{Corresponding Author:}

Inês Coutinho

inescorga@gmail.com 